\title{
Stability of pH, Blood Gas Partial Pressure, Hemoglobin Oxygen Saturation Fraction, and Lactate Concentration
}

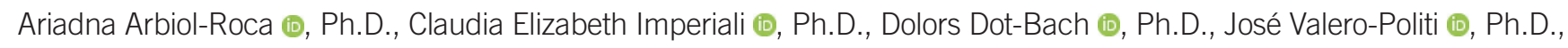
and Macarena Dastis-Arias (i), Ph.D.

Laboratori Clínic Territorial Metropolitana Sud-Hospital Universitari de Bellvitge. Hospitalet de Llobregat, Barcelona, Spain

Background: The storage temperature and time of blood gas samples collected in syringes constitute preanalytical variables that could affect blood gas or lactate concentration measurement results. We analyzed the effect of storage temperature and time delay on arterial or venous blood gas stability related to $\mathrm{pH}$, partial pressure of carbon dioxide $\left(\mathrm{pCO}_{2}\right)$ and oxygen $\left(\mathrm{pO}_{2}\right)$, hemoglobin oxygen saturation $\left(\mathrm{sO}_{2}\right)$, and lactate concentration.

Methods: In total, 1,200 arterial and venous blood sample syringes were analyzed within 10 minutes of collection. The samples were divided into different groups to determine parameter stability at $25,4-8$, and $0-3.9^{\circ} \mathrm{C}$ and at different storage times, $60,45,30$, and 15 minutes. Independent sample groups were used for each analysis. Percentage deviations were calculated and compared with acceptance stability limits ( $1.65 \times$ coefficient of variation). Additionally, sample group sub analysis was performed to determine whether stability was concentration-dependent for each parameter.

Results: The $\mathrm{pH}$ was stable over all storage times at $4-8$ and $0-3.9^{\circ} \mathrm{C}$ and up to $30 \mathrm{~min}$ utes at $25^{\circ} \mathrm{C} . \mathrm{pCO}_{2}$ was stable at $\leq 60$ minutes at all temperatures. $\mathrm{pO}_{2}$ was stable for 45 minutes at $0-3.9^{\circ} \mathrm{C}$, and $\mathrm{sO}_{2}$ was stable for 15 minutes at $25^{\circ} \mathrm{C}$ and for $\leq 60$ minutes at $0-3.9^{\circ} \mathrm{C}$. Lactate concentration was stable for 45 minutes at $0-3.9^{\circ} \mathrm{C}$. Subanalysis showed that stability was concentration-dependent.

Conclusions: The strictest storage temperature and time criteria $\left(0-3.9^{\circ} \mathrm{C}, 45\right.$ minutes) should be adopted for measuring $\mathrm{pH}, \mathrm{pCO}_{2}, \mathrm{pO}_{2}, \mathrm{sO}_{2}$, and lactate concentration in blood gas syringes.

Key Words: Stability, Blood gases, Storage, Temperature, Time, Preanalytical variables.
Received: October 18, 2019

Revision received: February 24, 2020

Accepted: June 1, 2020

\section{Corresponding author:}

Ariadna Arbiol-Roca, Ph.D.

Laboratori Clínic Territorial Metropolitana Sud-Hospital Universitari de Bellvitge, 08907 Hospitalet de Llobregat, Barcelona, Spain

Tel: +34932607500

E-mail: ariadna.arbiol@bellvitgehospital.cat

\section{INTRODUCTION}

Most errors affecting total blood analysis occur during the preanalytical phase, mainly owing to a lack of standardized procedures for samples collection, for example, the correct homogenization of samples and removal of air bubbles [1]. The storage temperature and time of the syringes with collected samples are additional preanalytical variables that can affect results of blood gases or lactate concentration [2]. To minimize the influence of these preanalytical variables on the results, the laboratory are responsible to inform practitioners about the preanalytical conditions under which samples should be collected, stored, and transported [3].

Some guidelines recommend analyzing blood samples within 30 minutes after collection and keeping them at a low temperature [4-7]; however, there is no agreement between the bio- 
chemical parameters and sampling conditions for syringes with collected samples in the literature. Previous studies have used different criteria for their calculations based on statistical, metrological, or biological variability, and as a result, suggested different recommendations [8-13]. Therefore, establishment of stability limits depends on the mathematical criterion defined. Laboratories may calculate their own stability limits under specific sample storage conditions using the mathematical criteria recommended by scientific societies or clinical guidelines [14, 15].

Previous studies have investigated stability effects $[12,13$, $16]$, kind of syringes $[8,13,17]$, different storage temperatures [7-9, 13, 18], transport conditions [7], and even syringe volumes $[12,13]$. However, despite the apparently vast bibliography, there is poor consensus about blood gas stability in daily practice. Therefore, we performed the main stability study with a large number of samples. We aimed to analyze the effects of temperature and duration of storage on the arterial or venous blood gas stability in samples in terms of $\mathrm{pH}$, partial pressure of carbon dioxide $\left(\mathrm{pCO}_{2}\right)$ and oxygen $\left(\mathrm{pO}_{2}\right)$, hemoglobin oxygen saturation $\left(\mathrm{s}_{2}\right)$, and lactate concentration. Moreover, for the first time, to the best of our knowledge, we explored the blood gas stability by grouping the samples based on the initial concentration for each parameter, to determine whether stability is concentration-dependent.

\section{MATERIALS AND METHODS}

The study, performed in the Stat Laboratory of Bellvitge University Hospital, Hospitalet de Llobregat, Barcelona, Spain, was approved by the Clinical Research Ethics Committee of Bellvitge University Hospital (Ref. PR297/12).

\section{Sample details}

The study was performed with blood samples obtained from the Intensive Care Unit and the Emergency Department. From June 2012 to January 2013, 1,200 arterial and venous blood samples were collected into SafePICO (Ref. 956-622; Radiometer) and Marquest's Quick ABG syringes (Ref. 4023TRU; Vyaire Medical, Höchberg, Germany); both syringes contain dried lyophilized lithium heparin (60-100 UI) as an anticoagulant. The study team collected the samples at the patient's point-of-care to ensure that these reached the laboratory in less than 10 minutes after collection. Informed consent was not obtained from the patients because the samples were randomized and anonymized. We collected a sufficient number of samples to ensure a minimum of 30 samples for each parameter at each specific time. Follow- ing the elimination of aberrant data pairs, a total of 1,147 samples were used.

The blood sample syringes used in our study were considered residual material; therefore, instead of discarding the samples once analyzed and validated, they were incubated at specific goal temperatures. In fact, each syringe was analyzed twice (time 0 minute and then incubated at the goal temperature for 60,45 , 30 , or 15 minutes, respectively).

\section{First measurement}

Before analysis, all samples were thoroughly mixed for 5-10 seconds by vertical hand-rolling, and any visible air bubbles were carefully removed. The $\mathrm{pH}, \mathrm{pCO}_{2}, \mathrm{pO}_{2}, \mathrm{sO}_{2}$, and lactate concentration in each blood sample were measured for the first time (basal measurement, time 0 minute) using an ABL800 blood gas analyser (Radiometer, Copenhagen, Denmark).

\section{Storage temperature}

Following the first analysis, the samples were grouped into three categories according to the storage temperature over $60 \mathrm{~min}$ utes: the first group samples were stored at $25^{\circ} \mathrm{C}$, the second group samples at $4-8^{\circ} \mathrm{C}$, and the third group samples at $0-3.9^{\circ} \mathrm{C}$ in an ice-water bath. Samples were randomly left at each goal temperature. The temperature was continuously monitored using a mercury-in-glass thermometer.

\section{Storage time and second measurement}

The stability study began by storing the samples for 60 minutes. After the desired time at the indicated temperature, the samples were quickly hand-mixed and reanalyzed. The first and second results were stored in a database, and statistical calculations were performed. If any parameter was not stable $\leq 60$ minutes, the study of that sample group started again with new samples, for 45 minutes. If stability was still an issue, the experiment was carried out for 30 and 15 minutes, sequentially. Independent sample groups were used each time (Fig. 1).

\section{Main study and substudy}

For the main study, stability was assessed with all data. For the substudy, all data were sorted into groups based on the initial values; $\mathrm{pH}, \mathrm{pCO}_{2}$, and $\mathrm{pO}_{2}$ data were divided into the following three groups: below, between, and above the reference intervals. The $\mathrm{sO}_{2}$ data and lactate concentration data were divided into two groups, below and above the reference intervals. 


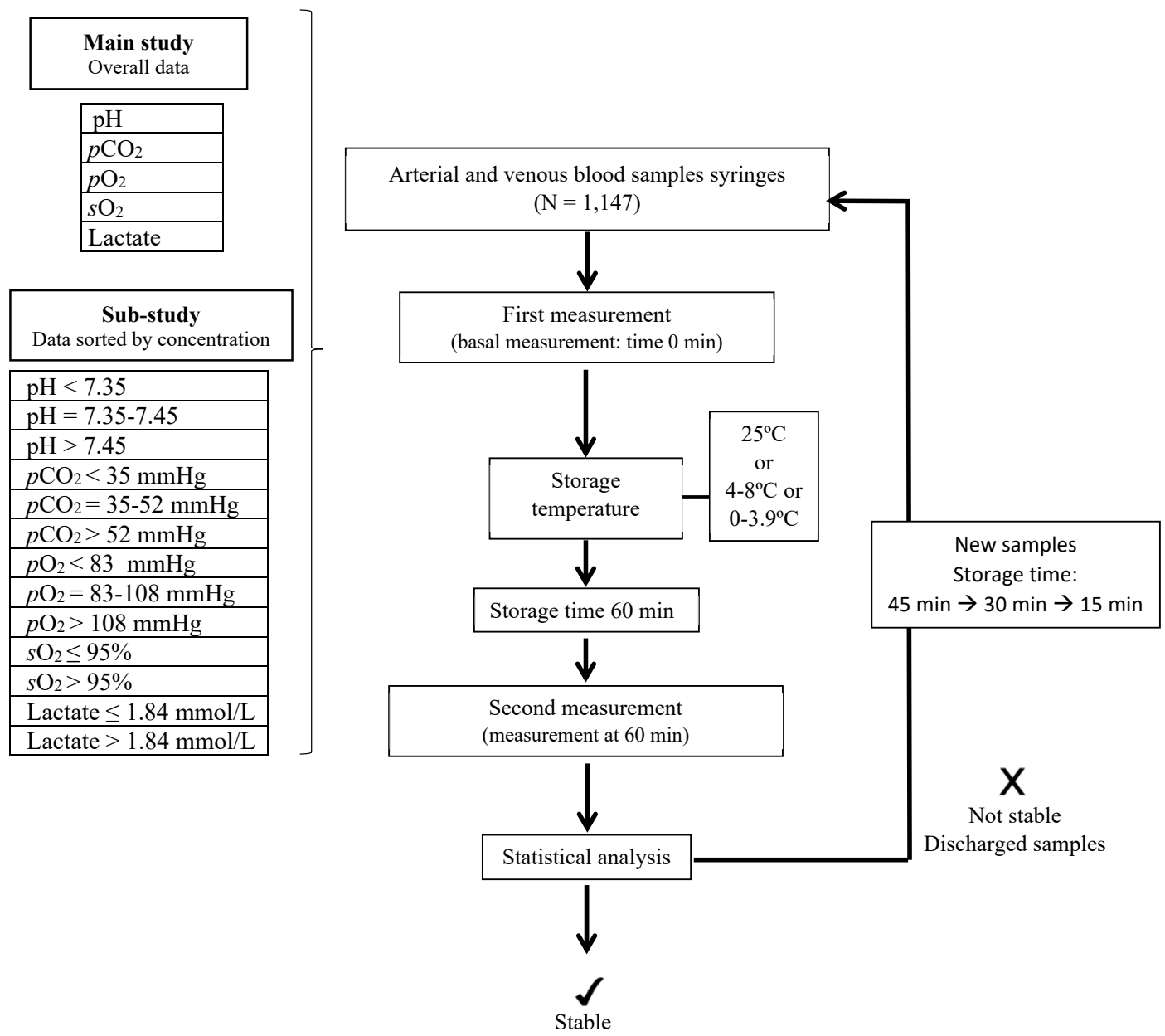

Fig. 1. Study flow diagram. The stability study began with storing the samples for 60 minutes. If any parameter was not stable for $\leq 60$ minutes, the study was started again with new samples for 45 minutes. If stability was still an issue, the experiment was carried out for 30 and 15 minutes, sequentially. Independent sample groups were used each time. Measurements were conducted using an ABL800 analyzer (Radiometer, Copenhagen, Denmark).

Abbreviations: $\mathrm{pCO}_{2}$, partial pressure of carbon dioxide; $\mathrm{pO}_{2}$, partial pressure of oxygen; $\mathrm{SO}_{2}$, oxygen saturation.

\section{Statistical analysis}

Acceptance stability limits (S) were obtained based on the Sociedad Española de Medicina de Laboratorio criteria for maximum allowable bias $(S= \pm 1.65$ coefficient of variation [CV]) [14]. The within-run imprecision, expressed as $\mathrm{CV}$, was calculated from the differences between pairs of duplicate measurements analyzing at least 60 samples using the Dahlberg formula $(s=\sqrt{ }$ $\Sigma d^{2} /^{2} n$ ). The aberrant differences between pairs of duplicate measurements were eliminated using the Bland-Altman method. For the main study, the CV was calculated for each parameter using the overall data. For the substudy, the CV was calculated for each parameter and for each concentration range.

The percentage deviation (PD) between the first measurement $\left(X_{i}\right)$ and the second measurement $\left(Y_{i}\right)$ for each parameter and storage condition were calculated as follows: $\mathrm{PD}=100(\Sigma(Y i-X i) /$
$X i) / n$. The PD was compared with the S; if the PD was greater than $\mathrm{S}$, the storage temperature and time caused a stability loss.

Statistical calculations were performed with Microsoft Excel 2010 (Microsoft Corp., Redmond, WA, USA), and the BlandAltman method was performed using Analyse-IT software (Analyse-IT software Ltd., Leeds, UK). The level of significance was defined at $P<0.05$.

\section{RESULTS}

\section{Within-run imprecision study}

The $\mathrm{CV}$ values of the main study (overall data) and the substudy (by concentration group) are shown in Table 1. All CV values achieved the maximum allowed values according to the metrological requirements of our laboratory. S was calculated with these $\mathrm{CV}$ values. 


\section{Arbiol-Roca A, et al.}

Preanalytical variables in blood gas analysis

Table 1. Within-run imprecision in overall group and in groups sorted by concentration

\begin{tabular}{llccccc}
\hline Within-run imprecision & $\begin{array}{c}\text { Mean (N) overall } \\
\text { Main Study }\end{array}$ & $\begin{array}{c}\text { Mean (N) by groups } \\
\text { Substudy }\end{array}$ & $\begin{array}{c}\text { CV requirement } \\
(\%)\end{array}$ & $\begin{array}{c}\text { CV overall (\%) } \\
\text { Main Study }\end{array}$ & $\begin{array}{c}\text { CV by groups (\%) } \\
\text { Substudy }\end{array}$ \\
\hline $\mathrm{pH}$ & $>7.35$ & $7.39(90)$ & $7.30(30)$ & 0.20 & 0.06 & 0.07 \\
& $7.35-7.45$ & & $7.40(30)$ & & & 0.04 \\
& $>7.45$ & & $7.49(30)$ & & & 0.06 \\
$\mathrm{pCO}_{2}(\mathrm{mmHg})$ & $<35.0$ & $45.4(90)$ & $30.7(30)$ & 4.00 & 2.02 & 1.68 \\
& $35.0-52.0$ & & $42.6(30)$ & & & 1.65 \\
& $>52.0$ & & $64.0(30)$ & & & 2.07 \\
$\mathrm{pO}_{2}(\mathrm{mmHg})$ & $<83.0$ & $108.6(91)$ & $45.9(31)$ & 7.00 & 5.62 & 5.35 \\
& $83.0-108.0$ & & $107.0(30)$ & & & 6.38 \\
& $>108.0$ & & $174.8(30)$ & & & 4.37 \\
$\mathrm{SO} \mathrm{O}_{2}(\%)$ & $\leq 95.0$ & $83.1(61)$ & $68.9(31)$ & 7.00 & 2.27 & 3.88 \\
& $>95.0$ & & $97.7(30)$ & & & 2.72 \\
$\mathrm{Lactate}(\mathrm{mmol} / \mathrm{L})$ & $\leq 1.84$ & $2.35(60)$ & $1.20(30)$ & 13.00 & 3.57 & 5.75 \\
& $>1.84$ & & $3.53(30)$ & & & 2.84 \\
\hline
\end{tabular}

Abbreviations: $\mathrm{CV}$, coefficient of variation; $\mathrm{N}$, number; $\mathrm{pCO}_{2}$, partial pressure of carbon dioxide; $\mathrm{pO}_{2}$, partial pressure of oxygen; $\mathrm{sO}_{2}$, oxygen saturation.

Table 2. Evaluation of sample storage temperature $\left(25,4-8\right.$, and $\left.0-3.9^{\circ} \mathrm{C}\right)$ and duration of biological parameter stability (in minutes) in all samples (overall group-main study)

\begin{tabular}{|c|c|c|c|c|c|}
\hline & $\mathrm{N}$ & Temperature $\left({ }^{\circ} \mathrm{C}\right)$ & Time (min) & $\mathrm{PD}(95 \% \mathrm{Cl})(\%)^{*}$ & $S(\%)^{\dagger}$ \\
\hline \multirow[t]{3}{*}{$\mathrm{pH}$} & 92 & 25 & 30 & $-0.090(-0.114 ;-0.066)$ & 0.099 \\
\hline & 97 & $4-8$ & $\leq 60$ & $-0.003(-0.028 ; 0.022)$ & \\
\hline & 89 & $0-3.9$ & $\leq 60$ & $-0.045(-0.071 ;-0.019)$ & \\
\hline \multirow[t]{3}{*}{$p \mathrm{CO}_{2}$} & 90 & 25 & $\leq 60$ & $2.81(2.15 ; 3.47)$ & 3.33 \\
\hline & 110 & $4-8$ & $\leq 60$ & $0.405(-0.043 ; 0.853)$ & \\
\hline & 90 & $0-3.9$ & $\leq 60$ & $0.070(-0.395 ; 0.535)$ & \\
\hline \multirow[t]{3}{*}{$\mathrm{pO}_{2}$} & 84 & 25 & $<15$ & $10.2(7.25 ; 13.1)$ & 9.27 \\
\hline & 190 & $4-8$ & $<15$ & $12.2(10.7 ; 13.6)$ & \\
\hline & 66 & $0-3.9$ & 45 & $8.09(5.15 ; 11.0)$ & \\
\hline \multirow[t]{3}{*}{$\mathrm{sO}_{2}$} & 66 & 25 & 15 & $2.37(1.56 ; 3.18)$ & 3.75 \\
\hline & 104 & $4-8$ & $<15$ & $7.68(6.59 ; 8.76)$ & \\
\hline & 81 & $0-3.9$ & $\leq 60$ & $3.71(2.57 ; 4.84)$ & \\
\hline \multirow[t]{3}{*}{ Lactate } & 65 & 25 & $<15$ & $14.0(10.8 ; 17.1)$ & 5.89 \\
\hline & 39 & $4-8$ & $<15$ & $8.13(6.46 ; 9.81)$ & \\
\hline & 27 & $0-3.9$ & 45 & $5.22(3.09 ; 7.34)$ & \\
\hline
\end{tabular}

PD in bold indicates significant stability time $(\mathrm{PD}<\mathrm{S})$. Groups that were stable for the entire study period are identified as $\leq 60$, while those that were not stable for even 15 min are designated as $<15$.

${ }^{*} \mathrm{PD}(\%)$ calculated as $\left.\Sigma\left(Y_{i}-X_{i}\right) / X i\right) / n \times 100$. The first $(X i)$ and the second $\left(Y_{i}\right)$ sample result for each parameter and storage condition; ${ }^{\dagger} S(\%)$ calculated as a coefficient of variation (CV) percentage overall (within-run imprecision) $\times 1.65$.

Abbreviations: N, number; Time (minute), elapsed time from baseline; PD, percentage deviation; $\mathrm{Cl}$, confidence interval; S (\%), acceptance stability limit; $\mathrm{pCO}_{2}$, partial pressure of carbon dioxide; $\mathrm{pO}_{2}$, partial pressure of oxygen; $\mathrm{SO}_{2}$, oxygen saturation.

\section{Main study}

The effect of storage temperature $\left(25,4-8\right.$, and $\left.0-3.9^{\circ} \mathrm{C}\right)$ and storage time on the stability of biological parameters in the main study is plotted in Fig. 2 and the data are shown in Table 2.

Blood $\mathrm{pH}$ was stable over all time periods when the sample was preserved via refrigeration $\left(0-3.9^{\circ} \mathrm{C}\right.$ or $\left.4-8^{\circ} \mathrm{C}\right)$ or up to 30 

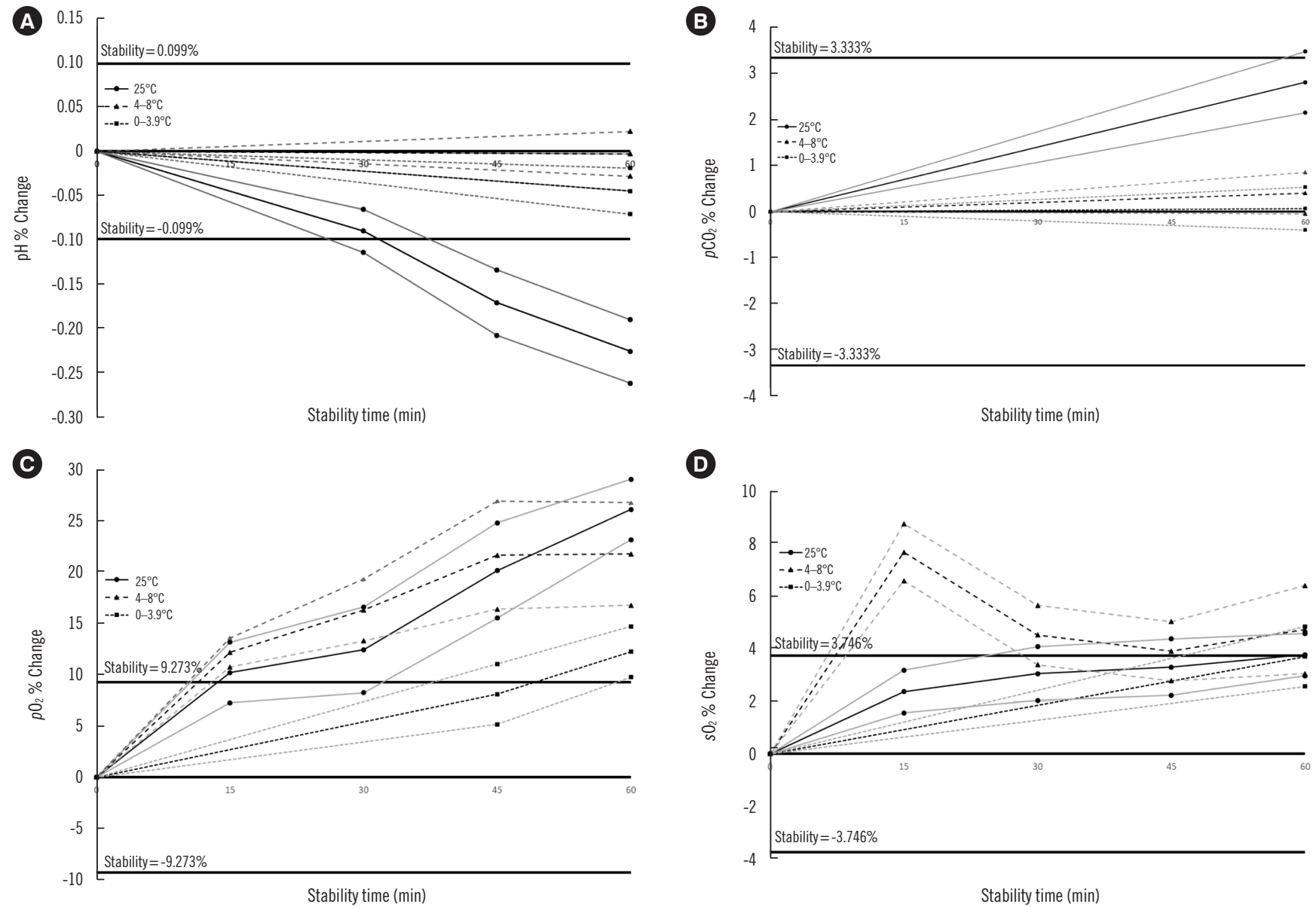

(D)

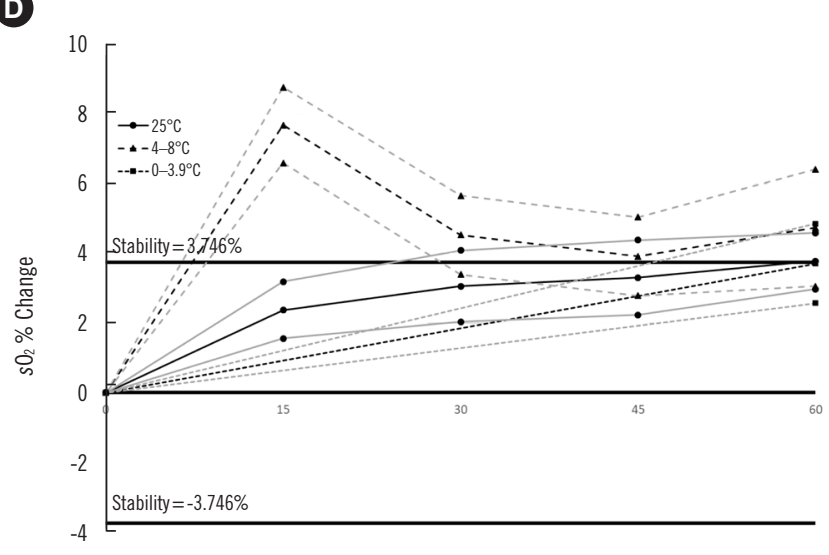

Stability time (min)

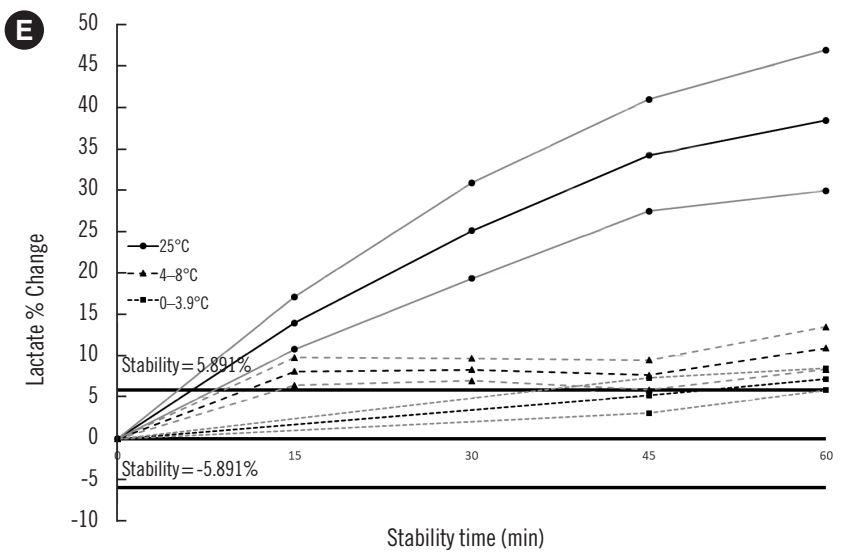

Fig. 2. Mean bias from baseline for $\mathrm{pH}(\mathrm{A}), \mathrm{pCO}_{2}(\mathrm{~B}), \mathrm{pO}_{2}(\mathrm{C}), \mathrm{sO}_{2}$ (D), and lactate concentration (E) at $25^{\circ} \mathrm{C}$ (solid black curve), $4-8^{\circ} \mathrm{C}$ (long dashed black curve), and $0-3.9^{\circ} \mathrm{C}$ (short dashed black curve). The two adjacent grey curves on either side represent the 95\% confidence interval of the mean curve. The solid black lines correspond to stability (\%) calculated as a CV percentage overall (withinrun imprecision) $\times 1.65$. Data are displayed in Table 2 . Independent sample groups were used for each time, even though there is a connection between lines.

Abbreviations: $\mathrm{pCO}_{2}$, partial pressure of carbon dioxide; $\mathrm{pO}_{2}$, partial pressure of oxygen; $\mathrm{SO}_{2}$, oxygen saturation; $\mathrm{CV}$, coefficient of variation.

minutes at $25^{\circ} \mathrm{C}$. For $p \mathrm{CO}_{2}$, no significant stability loss was observed in any sample for $\leq 60$ minutes. The $\mathrm{pO}_{2}$ values were not stable for 15 minutes at $25^{\circ} \mathrm{C}$ or $4-8^{\circ} \mathrm{C}$, but were stable at 45 minutes when the sample was preserved at $0-3.9^{\circ} \mathrm{C} . \mathrm{SO}_{2}$ was stable for 15 minutes at $25^{\circ} \mathrm{C}$ and $\leq 60$ minutes at $0-3.9^{\circ} \mathrm{C}$. In contrast, $\mathrm{sO}_{2}$ was not stable at $4-8^{\circ} \mathrm{C}$ for 15 minutes. Lactate concentration was not stable for any time at $25^{\circ} \mathrm{C}$ or $4-8^{\circ} \mathrm{C}$; however, it was stable for 45 minutes at $0-3.9^{\circ} \mathrm{C}$.

\section{Substudy}

Table 3 shows the results of the samples sorted according to the initial value of the blood gas parameters.

Blood $\mathrm{pH}$ was stable for all storage times when it was preserved at $4-8$ or $0-3.9^{\circ} \mathrm{C}$, for the three groups. It was also stable for 30 minutes at $25^{\circ} \mathrm{C}$ in the group below the lower limit of the reference interval and for 15 minutes within and above the upper limit of the reference interval. Similarly, $p \mathrm{CO}_{2}$ was stable at 4-8 
Table 3. Evaluation of sample storage temperature $\left(25,4-8\right.$, and $\left.0-3.9^{\circ} \mathrm{C}\right)$ and duration of biological parameter stability (in minutes) sorted by the initial concentration value (substudy)

\begin{tabular}{|c|c|c|c|c|c|c|c|c|c|c|c|c|}
\hline Temperature $\left({ }^{\circ} \mathrm{C}\right)$ & $\mathrm{N}$ & Time (min) & $\mathrm{PD}(\%)^{*}$ & $S(\%)^{\dagger}$ & $\mathrm{N}$ & Time (min) & $\mathrm{PD}(\%)^{*}$ & $S(\%)^{\dagger}$ & $\mathrm{N}$ & Time (min) & $\mathrm{PD}(\%)^{*}$ & $S(\%)^{\dagger}$ \\
\hline & \multicolumn{4}{|c|}{$\mathrm{pH}<7.35$} & \multicolumn{4}{|c|}{$\mathrm{pH}=7.35-7.45$} & \multicolumn{4}{|c|}{$\mathrm{pH}>7.45$} \\
\hline 25 & 30 & 30 & 0.088 & 0.116 & 29 & 15 & 0.038 & 0.066 & 29 & 15 & 0.020 & 0.099 \\
\hline $4-8$ & 30 & $\leq 60$ & 0.023 & & 36 & $\leq 60$ & 0.032 & & 31 & $\leq 60$ & 0.051 & \\
\hline \multirow[t]{2}{*}{$0-3.9$} & 29 & $\leq 60$ & 0.088 & & 31 & $\leq 60$ & 0.015 & & 29 & $\leq 60$ & 0.024 & \\
\hline & \multicolumn{4}{|c|}{$\mathrm{pCO}_{2}<35 \mathrm{mmHg}$} & \multicolumn{4}{|c|}{$p \mathrm{CO}_{2}=35-52 \mathrm{mmHg}$} & \multicolumn{4}{|c|}{$p \mathrm{CO}_{2}>52 \mathrm{mmHg}$} \\
\hline 25 & 25 & 30 & 0.304 & 2.77 & 32 & 45 & 0.021 & 2.72 & 27 & $\leq 60$ & 0.618 & 3.42 \\
\hline $4-8$ & 31 & $\leq 60$ & 0.203 & & 55 & $\leq 60$ & 0.605 & & 24 & $\leq 60$ & 0.206 & \\
\hline \multirow[t]{2}{*}{$0-3.9$} & 33 & $\leq 60$ & 0.193 & & 31 & $\leq 60$ & 0.520 & & 26 & $\leq 60$ & 0.612 & \\
\hline & \multicolumn{4}{|c|}{$\mathrm{pO}_{2}<83 \mathrm{mmHg}$} & \multicolumn{4}{|c|}{$\mathrm{pO}_{2}=83-108 \mathrm{mmHg}$} & \multicolumn{4}{|c|}{$p 0_{2}>108 \mathrm{mmHg}$} \\
\hline 25 & 34 & 15 & 8.68 & 8.83 & 26 & $<15$ & 17.8 & 10.5 & 27 & 30 & 3.93 & 7.21 \\
\hline $4-8$ & 116 & $<15$ & 10.6 & & 31 & $<15$ & 17.2 & & 43 & $<15$ & 12.8 & \\
\hline \multirow[t]{2}{*}{$0-3.9$} & 53 & $\leq 60$ & 6.99 & & 30 & $<15$ & 18.7 & & 34 & $<15$ & 16.6 & \\
\hline & \multicolumn{4}{|c|}{$\mathrm{sO}_{2} \leq 95 \%$} & \multicolumn{4}{|c|}{$\mathrm{sO}_{2}>95 \%$} & & & & \\
\hline 25 & 33 & 15 & 4.38 & 6.40 & 33 & $\leq 60$ & 0.379 & 4.49 & & & & \\
\hline $4-8$ & 104 & $<15$ & 7.68 & & 33 & $\leq 60$ & 0.566 & & & & & \\
\hline \multirow[t]{2}{*}{$0-3.9$} & 49 & $\leq 60$ & 5.56 & & 32 & $\leq 60$ & 1.87 & & & & & \\
\hline & \multicolumn{4}{|c|}{ Lactate $\leq 1.84 \mathrm{mmol} / \mathrm{L}$} & \multicolumn{4}{|c|}{ Lactate $>1.84 \mathrm{mmol} / \mathrm{L}$} & & & & \\
\hline 25 & 36 & $<15$ & 18.6 & 9.49 & 29 & $<15$ & 8.23 & 4.69 & & & & \\
\hline $4-8$ & 25 & $<15$ & 10.5 & & 14 & 15 & 3.89 & & & & & \\
\hline $0-3.9$ & 44 & $\leq 60$ & 8.03 & & 29 & $\leq 60$ & 2.34 & & & & & \\
\hline
\end{tabular}

Groups that were stable for the entire study period are identified as $\leq 60$, while those that were not stable for even 15 minutes are designated as $<15$. PD in bold indicates significant stability time $(\mathrm{PD}<\mathrm{S})$.

${ }^{*} \mathrm{PD}(\%)$ calculated as $\left.\Sigma(Y i-X i) / X i\right) / n \times 100$. The first $(X i)$ and the second $(Y i)$ sample result for each parameter and storage condition; ${ }^{\dagger} \mathrm{S}(\%)$ calculated as a coefficient of variation $(\mathrm{CV})$ percentage overall (within-run imprecision) $\times 1.65$.

Abbreviations: N, number; time (min), elapsed time from baseline; PD, percentage deviation; $\mathrm{S}(\%)$, acceptance stability limit; $\mathrm{pCO}_{2}$, partial pressure of carbon dioxide; $\mathrm{pO}_{2}$, partial pressure of oxygen; $\mathrm{sO}_{2}$, oxygen saturation.

and $0-3.9^{\circ} \mathrm{C}$ for all samples. At $25^{\circ} \mathrm{C}, p \mathrm{CO}_{2}$ was stable for 30 minutes in the group below the lower limit, 45 minutes in the group within, and $\leq 60$ minutes in the group above the upper limit of the reference interval. $\mathrm{pO}_{2}$ was not stable at 15 minutes in nearly all groups at any of the storage temperatures. The exception was the group above the upper limit $\left(\mathrm{pO}_{2}>108 \mathrm{mmHg}\right)$ at $25^{\circ} \mathrm{C}$, which was stable for 30 minutes, and the group below the lower limit $\left(\mathrm{pO}_{2}<83 \mathrm{mmHg}\right)$ at $0-3.9^{\circ} \mathrm{C}$, which was stable for $\leq 60$ minutes. $\mathrm{sO}_{2}$ was stable under all conditions in the group above the upper limit ( $>95 \%$ ), but was only stable at $0-3.9^{\circ} \mathrm{C}$ $\leq 60$ minutes in the group below the upper limit $(\leq 95 \%)$. Lactate concentration was stable at all times for $0-3.9^{\circ} \mathrm{C}$ in both groups, and the lactate group $>1.84 \mathrm{mmol} / \mathrm{L}$ was stable at $4-8^{\circ} \mathrm{C}$, 15 minutes. However, it was not stable in either concentration group at $25^{\circ} \mathrm{C}$, or in the lactate group $\leq 1.84 \mathrm{mmol} / \mathrm{L}$ at $4-8^{\circ} \mathrm{C}$.

\section{DISCUSSION}

Previous stability studies regarding the measurement of blood gases are outdated and present contradictory data. Each study differs in terms of design, blood sample volume, initial oxygen concentration, syringe type, and size, resulting in different conclusions [8-13]. We carried out a stability study with added value using a large number of samples and by grouping the samples by the initial value of each parameter, to determine whether stability is concentration-dependent. Our findings agree with the findings by Srisan, et al. [18], who did not observe a significant decrease in $\mathrm{pH}$ over time until 30 minutes at $25^{\circ} \mathrm{C}$ and $45 \mathrm{~min}$ utes on ice. Similarly, Smajic, et al. [16] observed no statistically significant differences in $\mathrm{pCO}_{2}$ values during 60 minutes at $25^{\circ} \mathrm{C}$.

Cell metabolism at $25^{\circ} \mathrm{C}$ could explain this phenomenon, as $\mathrm{CO}_{2}$ is generated both aerobically and anaerobically, leading to an increase in $\mathrm{pCO}_{2}$ and a decrease in $\mathrm{pH}$. Williams, et al. [19] 
showed that for every increase in $\mathrm{pCO}_{2}$ by $20 \mathrm{mmHg}$ above normal, the $\mathrm{pH}$ decreased by 0.1 unit, while for every decrease of $p \mathrm{CO}_{2}$ by $10 \mathrm{mmHg}$ below normal, the $\mathrm{pH}$ increased by 0.1 unit. However, lower temperatures reduce oxygen consumption and $\mathrm{CO}_{2}$ production [12]. In general, samples collected under anaerobic conditions in plastic heparinized syringes, kept at $25^{\circ} \mathrm{C}$, showed significant stability losses. The $\mathrm{pO}_{2}$ decreased while $\mathrm{pCO}_{2}$ increased as a product of cell metabolism. As a consequence of increased $p \mathrm{CO}_{2}$ and the production of hydrogen ions, which are generated as a result of glycolysis, lactate concentration increased and the $\mathrm{pH}$ decreased. Baird, et al. [20] showed that a delay in analysis decreased $\mathrm{pO}_{2}$ by $2 \mathrm{mmHg} / \mathrm{hr}$ and increased $p \mathrm{CO}_{2}$ by $1 \mathrm{mmHg} / \mathrm{hr}$ at room temperature. Consequently, blood $\mathrm{pH}$ decreased by $0.02-0.03 \mathrm{pH}$ units/hr at room temperature. It should be noted that these turnaround times are not unusual in some hospital circuits. Laboratory professionals should, therefore, help achieve optimum turnaround times [21, 22].

$\mathrm{pO}_{2}$ increased in the study groups, in which the $\mathrm{pO}_{2}$ of the samples was below the ambient value $(\approx 159 \mathrm{mmHg})$. If the $\mathrm{pO}_{2}$ in the blood gas is above the ambient value, the gas diffuses and, consequently, $\mathrm{pO}_{2}$ decreases [17]. Therefore, it was more stable in the group with higher partial pressures at $25^{\circ} \mathrm{C}$ than in the other groups at the same temperature. This could be due to the difference in the atmospheric $\mathrm{pO}_{2}$ and the gas diffusion through the wall of the plastic syringe. In concordance with a previous study, when atmospheric pressure was above that of the syringe, partial pressure diffusion causes slight changes compared to when the atmospheric pressure is below that of the syringe [23]. This also depends on the syringe material [8, 9, 24].

Considering our results, we recommend cooling $\left(0-3.9^{\circ} \mathrm{C}\right)$ sample syringes when $\mathrm{pO}_{2}$ is ordered and when there is a delay in processing the sample. In contrast, Baird, et al. [20] concluded that keeping glass syringes on ice after collection is no longer recommended for plastic syringes. The CLSI guidelines recommend that samples in plastic syringes should be analyzed within 30 minutes after collection at $25^{\circ} \mathrm{C}$ [25].

The sample extraction procedure should be rigorous since air aspiration or bubble formation in blood gas syringes can significantly alter blood gas parameters [26]. Exposure of a blood gas sample to air would typically result in an elevation or drop in $\mathrm{pO}_{2}$ to $150 \mathrm{mmHg}$ and perhaps a decrease in $\mathrm{pCO}_{2}$ along with an increase in $\mathrm{pH}$ due to the loss of carbonic acid at prolonged exposure [20].

Finally, lactate is a degradation product of the anaerobic pathway and may contribute to the decrease in $\mathrm{pH}$. When blood sample is collected, metabolism in blood cells is still active; blood cells consume oxygen and glucose, the sample becomes anaerobic, and lactate is produced, resulting in concomitant acidosis [20].

Our study has some limitations. First, the stability time was calculated not from sample collection but from the reception of syringe at the laboratory, taking into account that not more than 10 minutes pass between collection and analysis. We cannot exclude some degree of gas exchange in syringes that were opened during analysis, even though we re-capped them at the earliest. The second limitation concerns the samples, as we performed the study with arterial and venous samples in order to cover all measurement ranges. To calculate the PD, we mixed the arterial and venous blood gas results. The correlation between arterial and venous blood results is good for $\mathrm{pH}, \mathrm{pCO}_{2}$, and lactate [27]. Most data for $\mathrm{pO}_{2}$ and $\mathrm{sO}_{2}$ below the reference intervals ( $<83 \mathrm{mmHg}$ and $\leq 95 \%$, respectively) were from venous samples, while the data above the reference intervals ( $>108$ $\mathrm{mmHg}$ and $>95 \%$, respectively) were mostly from arterial samples. Third, possible hemolysis, icterus, and lipemia (HIL) interferences were not assessed, although we were aware that these could be present [28]. Lastly, the effect of sample handling in relation to other sources of inaccuracy in blood gas analysis should be considered [29, 30]. However, all samples were homogenized in the same way and processed by the study team, albeit without following any specific protocol.

In summary, requests for blood $\mathrm{pH}, \mathrm{pCO}_{2}, \mathrm{pO}_{2}, \mathrm{sO}_{2}$, or lactate are performed using the same sample, at the same time, and the initial concentration values are not known. Therefore, the strictest criteria for storage temperature should be adopted for all samples, i.e. at $0-3.9^{\circ} \mathrm{C}$ for 45 minutes. By identifying blood gas stability, laboratory staff could improve the circuits between the laboratory and the hospital. The point-of-care analysis will be implemented in the future; thus, studies are required to demonstrate that the quality of the results is good with improved turnaround times as well as higher patient safety and health care quality.

\section{ACKNOWLEDGEMENTS}

This study was supported by a grant from Fundación JL CastañoSEQC "María Rosa Concustell 2013." We wish to thank all laboratory staff that analyzed the blood sample syringes. In particular, Corral-Comesaña S and González de Aledo-Castillo JM, who were involved in the study. 


\section{AUTHOR CONTRIBUTIONS}

Study conception and design: ARA, ICE, DBD, VPJ, and DAM. Data acquisition and analysis: ARA and ICE. Analysis and interpretation of the data: ARA, ICE, DBD, VPJ, and DAM. Writing the manuscript: ARA and ICE. Reviewing and editing the manuscript: DBD, VPJ, and DAM. Final approval of the manuscript: ARA, ICE, DBD, VPJ, and DAM.

\section{CONFLICTS OF INTEREST}

No potential conflicts of interest relevant to this paper were reported.

\section{RESEARCH FUNDING}

None declared.

\section{ORCID}

Ariadna Arbiol-Roca https://orcid.org/0000-0002-5206-3818 Claudia Elizabeth Imperiali

$\begin{array}{ll} & \text { https://orcid.org/0000-0002-7130-922X } \\ \text { Dolors Dot-Bach } & \text { https://orcid.org/0000-0003-2642-8200 } \\ \text { José Valero-Politi } & \text { https://orcid.org/0000-0003-2949-000X } \\ \text { Macarena Dastis-Arias } & \text { https://orcid.org/0000-0003-3705-2739 }\end{array}$

\section{REFERENCES}

1. Bonini P, Plebani M, Ceriotti F, Rubboli F. Errors in laboratory medicine. Clin Chem 2002;48:691-8.

2. Thelen MHM and Huisman W. Harmonization of accreditation to ISO15189. Clin Chem Lab Med 2018;56:1637-43.

3. UNE-EN ISO 15189:2012. Medical laboratories-particular requirements for quality and competence.

4. AARC clinical practice guideline. Sampling for arterial blood gas analysis. American Association for Respiratory Care. Respir Care 1992;37: 913-7.

5. American Association for Respiratory Care. AARC Clinical Practice Guideline: blood gas analysis and hemoximetry: 2001 revision and update. Respir Care 2001;46:498-505.

6. Burnett RW, Covington AK, Fogh-Andersen N, Külpmann WR, Maas $\mathrm{AH}$, Müller-Plathe $\mathrm{O}$, et al. International federation of clinical chemistry (IFCC). Scientific division. Committee on $\mathrm{pH}$, blood gases and electrolytes. Approved IFCC recommendations on whole blood sampling, transport and storage for simultaneous determination of $\mathrm{pH}$, blood gases and electrolytes. Eur J Clin Chem Clin Biochem 1995;33:247-53.

7. Dukić L, Milevoj Kopčinović L, Dorotić A, Baršić I. Blood gas testing and related measurements: National recommendations on behalf of the Croatian Society of Medical Biochemistry and Laboratory Medicine. Biochem Med (Zagreb) 2016;26:318-36.
8. Mahoney JJ, Harvey JA, Wong RJ, Van Kessel AL. Changes in oxygen measurements when whole blood is stored in iced plastic or glass syringes. Clin Chem 1991;37:1244-8.

9. Liss HP and Payne CP Jr. Stability of blood gases in ice and at room temperature. Chest 1993;103:1120-2.

10. Schmidt $\mathrm{C}$ and Müller-Plathe $\mathrm{O}$. Stability of $\mathrm{pO}_{2}, \mathrm{pCO}_{2}$, and $\mathrm{pH}$ in heparinized whole blood samples: influence of storage temperature with regard to leukocyte count and syringe material. Eur J Clin Chem Clin Biochem 1992;30:767-73.

11. Beaulieu M, Lapointe $\mathrm{Y}$, Vinet B. Stability of $\mathrm{PO}_{2}, \mathrm{PCO}_{2}$, and $\mathrm{pH}$ in fresh blood samples stored in a plastic syringe with low heparin in relation to various blood-gas and hematological parameters. Clin Biochem 1999; 32:101-7.

12. Smeenk FW, Janssen JD, Arends BJ, Harff GA, van den Bosch JA, Schönberger JP, et al. Effects of four different methods of sampling arterial blood and storage time on gas tensions and shunt calculation in the $100 \%$ oxygen test. Eur Respir J 1997;10:910-3.

13. Pretto JJ and Rochford PD. Effects of sample storage time, temperature and syringe type on blood gas tensions in samples with high oxygen partial pressures. Thorax 1994; 49:610-2.

14. Alsina MJ, González-Oller RK, SEQC Laboratory Quality Assurance and Accreditation Committee. Definition of the stability limit of the parameters in the biological samples. Química Clínica 2006;25:81-5. (article in Spanish).

15. Ricós C, Cava F, García-Lario JV, Hernández A, Iglesias N, Jiménez CV, et al. The reference change value: A proposal to interpret laboratory reports in serial testing based on biological variation. Scand J Clin Lab Invest 2004;64:175-84.

16. Smajić J, Kadić D, Hasić S, Serdarević N. Effects of post-sampling analysis time, type of blood samples and collection tubes on values of blood gas testing. Med Glas (Zenica) 2015;12:108-12.

17. Knowles TP, Mullin RA, Hunter JA, Douce FH. Effects of syringe material, sample storage time, and temperature on blood gases and oxygen saturation in arterialized human blood samples. Respir Care 2006;51: 732-6.

18. Srisan P, Udomsri T, Jetanachai P, Lochindarat S, Kanjanapattanakul W. Effects of temperature and time delay on arterial blood gas and electroIyte measurements. J Med Assoc Thai 2011;94(S3):S9-14.

19. Williams AJ. ABC of oxygen: assessing and interpreting arterial blood gases and acid-base balance. BMJ 1998;317:1213-6.

20. Baird GB. Preanalytical considerations in blood gas analysis. Biochem Med (Zagreb) 2013;23:19-27.

21. Arbiol-Roca A and Dot-Bach D. Critical issues and new trends on stat tests in clinical laboratory. EJIFCC 2019;30:59-66.

22. Brazg J, Huang P, Weiner C, Singh G, Likourezos A, Salem L, et al. Relocation of blood gas laboratory to the emergency department helps decrease lactic acid values. Am J Emerg Med 2018;36:2035-7.

23. Gruber MA, Felbermeir S, Lindner R, Kieninger M. Preanalytics: the (in-) stability of volatile POCT parameters and the homogeneity of blood in syringes at the market. Clin Chim Acta 2016;457:18-23.

24. Mohammadhoseini E, Safavi E, Seifi S, Seifirad S, Firoozbakhsh S, Peiman S. Effect of sample storage temperature and time delay on blood gases, bicarbonate and $\mathrm{pH}$ in human arterial blood samples. Iran Red Crescent Med J 2015;17:e13577.

25. CLSI. Procedures for the collection of arterial blood specimens; approved standard. 4th ed. CLSI GP43-A4 (former H11-A4). Wayne, PA: Clinical and Laboratory Standards Institute. 2004.

26. Kieninger M, Zech N, Mulzer Y, Bele S, Seemann M, Künzig H, et al. Optimization of blood gas analysis in intensive care units: reduction of preanalytical errors and improvement of workflow. Anaesthesist 2015; 
64:365-72.

27. Murphy R, Thethy S, Raby S, Beckley J, Terrace J, Fiddler C, et al. Capillary blood gases in acute exacerbations of COPD. Respir Med 2006; 100:682-6.

28. Liu D, Li YX, Huang Y. Analysis of hemolysis, icterus and lipemia in arterial blood gas specimens. Clin Chem Lab Med 2017;55:e69-71.
29. Ruppel GL. Of time and temperature, plastic and glass: specimen handling in the blood-gas laboratory. Respir Care 2006;51:717-8.

30. Davis MD, Walsh BK, Sittig SE, Restrepo RD. AARC clinical practice guideline: blood gas analysis and hemoximetry: 2013. Respir Care 2013; 58:1694-703. 